\title{
Genetic Structure of Rhynchosporium secalis in Australia
}

\author{
B. A. McDonald, J. Zhan, and J. J. Burdon
}

First and second authors: Department of Plant Pathology and Microbiology, Texas A\&M University, College Station 77843-2132; third author: Centre for Plant Biodiversity Research, CSIRO-Plant Industry, G.P.O. Box 1600, Canberra, A.C.T. 2601, Australia.

Current address of B. A. McDonald and J. Zhan: Institute of Plant Sciences, Phytopathology Group, Federal Institute of Technology, ETHZentrum, LFW, CH-8092 Zürich, Switzerland.

Accepted for publication 11 May 1999.

\begin{abstract}
McDonald, B. A., Zhan, J., and Burdon, J. J. 1999. Genetic structure of Rhynchosporium secalis in Australia. Phytopathology 89:639-645.

Restriction fragment length polymorphism (RFLP) markers were used to determine the genetic structure of Australian field populations of the barley scald pathogen Rhynchosporium secalis. Fungal isolates were collected by hierarchical sampling from five naturally infected barley fields in different geographic locations during a single growing season. Genetic variation was high in Australian R. secalis populations. Among the 265 fungal isolates analyzed, 214 distinct genotypes were identified. Average genotype diversity within a field population was $65 \%$ of its theoretical maximum. Nei's average gene diversity across seven RFLP loci was 0.54 . The
\end{abstract}

ABSTRACT

Knowledge of the amount and distribution of genetic variation within and among populations is an important component of understanding the population biology of pathogenic fungi. Genetic structure can be used to infer the relative impact of different forces that influence the evolution of pathogen populations. In turn, a better understanding of evolutionary forces may allow us to predict the potential for pathogen populations to evolve in agricultural ecosystems (43). For example, a large amount of genetic diversity distributed over a small spatial scale suggests the possibility of rapid adaptation by a pathogen to a changing environment (e.g., new host resistance genes or fungicides). A high degree of genetic similarity among populations collected from widely separated geographic regions suggests the occurrence of significant long-distance dispersal and gene flow. Gene flow over long distances poses a threat to deployment of resistance genes tailored to local pathogen populations, because immigrants may possess virulence genes that can overcome resistance in local host cultivars. New virulence genes also might be incorporated into local pathogen populations through recombination (6).

The fungus Rhynchosporium secalis (Oudem.) J.J. Davis causes barley scald disease. $R$. secalis can be a significant pathogen anywhere barley crops are grown (42), causing 10 to $40 \%$ reductions in yield under favorable conditions $(1,23,37)$. It is thought that the primary inoculum of $R$. secalis consists of conidia dispersed by rainsplash or mycelia in infected seeds $(3,40)$. The teleomorph of $R$. secalis has not yet been identified.

Although the number of pathotypes identified in different parts of the world varies substantially (from 2 to 75 pathotypes have been identified in previous studies $[2,9,12,13,18,43]$ ), it appears that genetic variation in $R$. secalis populations is generally high

Corresponding author: B. A. McDonald

E-mail address: bruce.mcdonald@ipw.agrl.ethz.ch

Publication no. P-1999-0614-02R

(C) 1999 The American Phytopathological Society majority $(76 \%)$ of gene diversity was distributed within sampling site areas measuring $\approx 1 \mathrm{~m}^{2} ; 19 \%$ of gene diversity was distributed among sampling sites within fields; and 5\% of gene diversity was distributed among fields. Fungal populations from different locations differed significantly both in allele frequencies and genotype diversities. The degree of genetic differentiation was significantly correlated with geographic distance between populations. Our results suggest that the $R$. secalis population in Western Australia has a different genetic structure than populations in Victoria and South Australia.

Additional keywords: gene flow, genetic diversity, hierarchical diversity analysis.

$(7,8,20,25)$. Isolates secured from different scald lesions taken from the same plant and even different spores isolated from the same lesion may vary significantly for sporulation rate, virulence, and isozymes $(7,15,32)$. Furthermore, the virulence structure of populations of $R$. secalis may change significantly over a relatively short period of time $(50)$. Goodwin et al. $(13,14)$ used isozyme markers to study the genetic structure of $R$. secalis populations originating in different geographic regions. They found that a large proportion of the total genetic diversity was distributed within local populations.

Major resistance genes have been deployed in barley to control scald; however, these genes have frequently exhibited a finite life span due to the breakdown of resistance associated with selection for increased virulence in $R$. secalis populations $(16,49)$. To more effectively use resistance genes in plant-breeding programs, knowledge of the population biology of $R$. secalis would be useful (46). The principal objective of the current study was to use restriction fragment length polymorphism (RFLP) markers and hierarchical sampling to determine the genetic structure of $R$. secalis populations in Australia.

\section{MATERIALS AND METHODS}

Field sampling methods. Barley leaves infected with $R$. secalis were sampled from five locations in Australia during October and November of the 1996 barley-growing season. All leaf samples were collected in naturally infected fields near the end of the growing season. Each leaf was collected from a different plant or tiller. Collection 1 was a fine-scale transect sampling from the Wagga Wagga Agricultural Institute, New South Wales. Four parallel, 6-m transects separated by $18 \mathrm{~cm}$ were laid out in a plot sown to cv. Clipper barley. One infected leaf was collected every $30 \mathrm{~cm}$ along each transect (20 leaves per transect; Fig. 1). The remaining four collections were taken from farmer's fields by a larger scale hierarchical sampling strategy (Fig. 1). Collection 2 was from cv. O'Connor grown at Methul, New South Wales; col- 
lection 3 was from cv. Schooner grown at Rannock, New South Wales; collection 4 was from cv. Arapiles grown at Horsham, Victoria; and collection 5 was from cv. Stirling grown at Quindanning, Western Australia. For each field population, three sites were sampled along two parallel transects. Both transects and collection sites along transects were separated by $10 \mathrm{~m}$. Infected leaves (10 total) were sampled from each site within the field (60 leaves per field total). A total of 320 infected leaves were collected from the five locations.

Isolation and growth of $\boldsymbol{R}$. secalis strains. Leaves were placed in paper envelopes and allowed to air-dry at room temperature for at least 48 h. Dried leaves were wet for $10 \mathrm{~s}$ in $70 \%$ ethanol, surface-sterilized for $60 \mathrm{~s}$ in a $0.5 \%$ sodium hypochlorite solution, and rinsed in distilled water for $10 \mathrm{~s}$. Wet leaves were pressed dry between paper towels and placed on a plastic screen that rested on rubber bands above damp filter paper in a petri dish. Petri dishes were incubated in the dark at $15^{\circ} \mathrm{C}$ for $48 \mathrm{~h}$ to induce fungal growth and sporulation. Fine glass needles were used to remove small tufts of mycelia that emerged around lesion borders. In 58 cases, multiple lesions were sampled from the same leaf. In eight cases, more than one isolation was made from the same lesion. Mycelial tufts were transferred to petri dishes containing lima bean agar (LBA). After incubating at $15^{\circ} \mathrm{C}$ for 1 to 2 weeks, colonies were

A

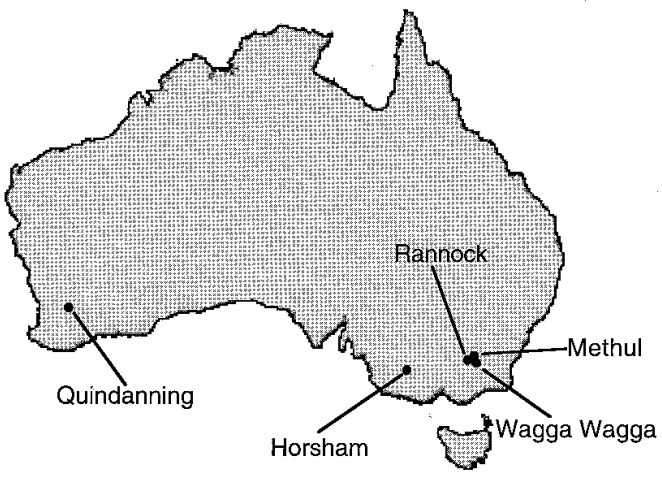

B

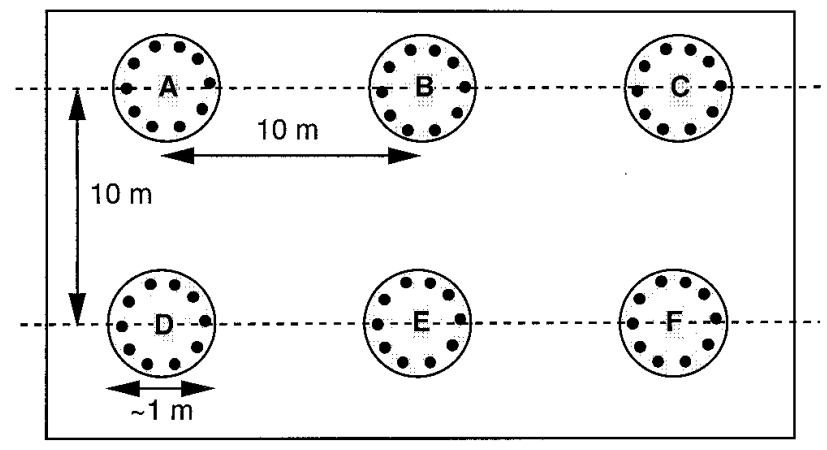

C

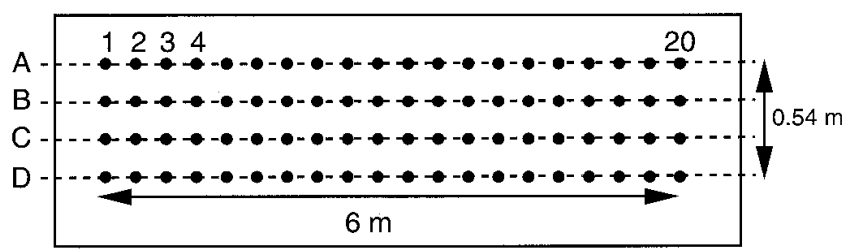

Fig. 1. Collection strategies used to sample field populations of Rhynchosporium secalis in Australia. A, Locations of five field populations sampled. B, Six-site ordered hierarchy (not drawn to scale). Ten infected leaves were sampled at regular intervals in a circular sweep from different plants or tillers at each field site. Three field sites were spaced at $10-\mathrm{m}$ intervals along two parallel transects separated by $10 \mathrm{~m}$. Sixty leaves total were sampled per field. C, High-density ordered transects (not drawn to scale). Infected leaves were collected at $30-\mathrm{cm}$ intervals over a 6-m transect. Four parallel transects were spaced $18 \mathrm{~cm}$ apart. Eighty leaves total were sampled per field. spread across fresh LBA plates and incubated for an additional 2 to 3 weeks at $15^{\circ} \mathrm{C}$. Spores and mycelial fragments were harvested by adding $1 \mathrm{ml}$ of sterile distilled water and scraping gently across the mycelium with a sterile glass microscope slide. The resulting slurry of spores and mycelium was used to inoculate $40-\mathrm{ml}$ flasks containing potato dextrose broth amended with kanamycin at $50 \mu \mathrm{g} / \mathrm{ml}$ and to inoculate $2.0-\mathrm{ml}$ cryovials (two-thirds full) containing silica gel for long-term storage. Inoculated flasks were incubated on a shaker at $15^{\circ} \mathrm{C}$ for 3 to 4 weeks.

DNA extraction. Mycelium was harvested by centrifugation in a 15-ml polypropylene centrifuge tube and lyophilized for $48 \mathrm{~h}$.
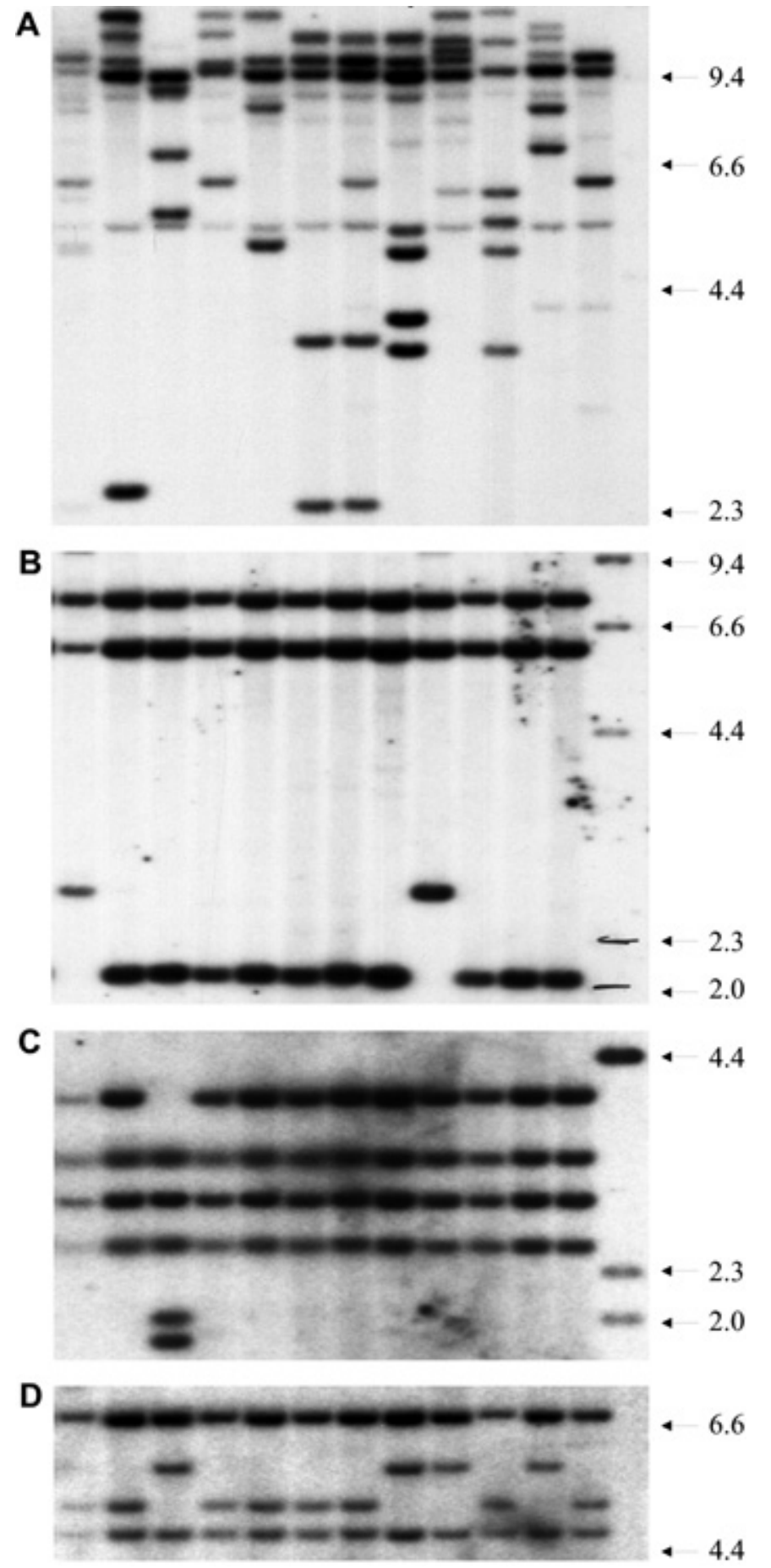

Fig. 2. Example restriction fragment length polymorphism alleles in 12 Australian isolates of Rhynchosporium secalis originating from one site in the Methul field population. $\lambda$-HindIII size standards are shown in the final lane to the right. A, Probe pRS26 produced a repetitive hybridization profile useful for DNA fingerprinting; B, probe pRS6; C, probe pRS49; and D, probe pRS2. 
Lyophilized tissue was crushed to a fine powder with a glass rod. Warmed $\left(42^{\circ} \mathrm{C}\right)$ extraction buffer $(5 \mathrm{ml}$ of $1 \%$ sodium lauroyl sarcosine, $150 \mathrm{mM}$ EDTA, $50 \mathrm{mM}$ Tris $\mathrm{pH}$ 8.0, and proteinase K [P8044, Sigma-RBI, Natick, MA] at $300 \mathrm{mg} / \mathrm{liter}$ ) was added to each tube and mixed with the powdered fungal tissue in a vortexer for 30 to $45 \mathrm{~s}$. Tubes were placed in a $42^{\circ} \mathrm{C}$ water bath for 10 to $30 \mathrm{~min}$. Phenol/chloroform/isoamyl alcohol (25:24:1, vol/vol; $5 \mathrm{ml})$ was added, and tubes were vortexed to form an emulsion. Tubes were centrifuged at $28,000 \times g$ for $10 \mathrm{~min}$ to separate phases. The aqueous phase was transferred to a fresh $15-\mathrm{ml}$ tube and extracted with an equal volume of chloroform/isoamyl alcohol (24:1, vol/vol). Phases were separated at $28,000 \times g$ for $10 \mathrm{~min}$. The aqueous phase was transferred to a fresh $15-\mathrm{ml}$ tube, and DNA was precipitated by mixing in 2 volumes of $95 \% \mathrm{EtOH}$ and 0.5 volumes of $7.5 \mathrm{M}$ ammonium acetate and left to stand at room temperature for $20 \mathrm{~min}$. DNA pellets were formed by centrifugation at $2,600 \times g$ for $10 \mathrm{~min}$ at room temperature. DNA pellets were dissolved in $400 \mu \mathrm{l}$ of Tris-EDTA buffer and transferred to $1.5-\mathrm{ml}$ microfuge tubes. DNA concentrations were determined with a fluorometer (DyNA Quant 200, Hoefer Pharmacia Biotech Inc., San Francisco).

Development of probes for RFLP analysis. A library of anonymous, random DNA fragments was constructed for use as probes. Total DNA from a randomly selected isolate of $R$. secalis collected in 1985 (RS14 [26]) was digested with BamHI. The resulting fragments were ligated into pUC18 and cloned in Escherichia coli by standard methods (24). Approximately 100 clones were picked for use as probes in RFLP analysis. Thirty-five randomly chosen clones were hybridized to DNA digested with PstI, EcoRI, HindIII, and BamHI from six Californian strains that had different isozyme phenotypes (26). On the basis of the preliminary screen, EcoRI was chosen as the most polymorphic enzyme, and eight probes were chosen for RFLP analysis based on strong, easily interpreted hybridization patterns. The eight probes were hybridized to DNA from $52 R$. secalis isolates from California that had been characterized previously for four isozyme loci (26). One of the probes (pRS26) hybridized to several well-separated fragments in each isolate, suggesting it might be useful for DNA fingerprinting.

Data analysis. For the seven probes that hybridized to single loci, each probe-enzyme combination was treated as a different RFLP locus. DNA fragments or combinations of fragments with different sizes were treated as alleles at each RFLP locus. Only alleles that could be scored unambiguously were included in the analysis. Multilocus haplotypes for each isolate were formed by joining the alleles present at each locus in the same order to form a seven-digit number that described the haplotype for each isolate. For the pRS26 probe, each hybridizing fragment profile was treated as a DNA fingerprint. Isolates with the same DNA fingerprint and multilocus haplotype were considered individual members of the same clone.

Genetic variation in each population was quantified by measures of gene (30) and genotype (41) diversity. Total gene diversity was partitioned into components among field populations, among sites within field populations, and within sites within field populations by hierarchical gene diversity analysis $(5,30)$. All hierarchical gene diversities were estimated by weighted gene frequencies for small and unequal sample sizes (30,31). Only the collections from Methul, Rannock, and Horsham were included in the hierarchical analysis. The Wagga Wagga collection was excluded because a nonhierarchical sampling method was used; the Quindanning (Western Australia) population was excluded because the genetic structure of the population was characterized by a higher degree of clonality that was significantly different from the other populations.

Similarities in the genetic structure of populations were evaluated based on contingency $\chi^{2}$ tests for differences in allele frequencies (45), Nei's (29) measure of genetic distance, and a Student's $t$ test for differences in genotype diversities (10). For the contingency $\chi^{2}$ test, alleles present at frequencies lower than 0.05 in all five populations were pooled into a single category. The $\chi^{2}$ value obtained by Workman and Niswander's method (45) was divided by two because $R$. secalis is a haploid organism. The results from the $\chi^{2}$ and $t$ tests were corrected by the Bonferroni procedure as proposed by Weir (44).

A test for isolation by distance was based on the method described by Slatkin (39). Gene flow was estimated based on the average $G_{\mathrm{ST}}$ (population differentiation) across seven RFLP loci (30), using the formula $\mathrm{Nm}=\left(1 / G_{\mathrm{ST}}-1\right) / 2$, where $\mathrm{Nm}$ is the average number of migrants exchanged between populations in each generation. If the degree of gene flow among populations is affected by geographic distance, we would expect to find a significant negative correlation between the logarithm of $\mathrm{Nm}$ and the logarithm of distance between populations (39).

\section{RESULTS}

RFLP probes. Of the 146 probe-enzyme combinations tested, 51 were polymorphic among the California isolates used in the screen for RFLPs. Of the 20 probes that appeared useful for RFLP analysis with EcoRI, 8 were used to characterize the Australian collections. Seven of the selected probes showed simple hybridization patterns consistent with a single genetic locus (Fig. 2). The eighth probe, pRS26, generated a complex hybridization pattern with the majority of California and Australian isolates assayed (Fig. 2). Although we did not validate the use of pRS26 for DNA fingerprinting in the Australian collections, in the California collection pRS26 hybridized to an average of 8.9 fragments between 2.0 and $9.4 \mathrm{~kb}$ in size in each isolate. For 36 scored fragments, the average frequency was 0.245 among the 52 California isolates. Using the method of Jeffrey et al. (19), we estimated that the average probability that two isolates chosen at random would have the same hybridization profile was $4 \times 10^{-6}$, suggesting pRS26 might be useful for DNA fingerprinting in other populations, including Australia.

Genetic variation in Australian R. secalis populations. A total of 265 isolates were included in the analysis of 5 Australian collections. The number of alleles found at 7 RFLP loci ranged from 2 to 5, with an average of 3.1 alleles per locus. For all RFLP loci, the summed frequency of the two most common alleles was at least $70 \%$ (Table 1). Significant levels of gene and genotype diversity

TABLE 1. Allele frequencies at seven restriction fragment length polymorphism (RFLP) loci in Australian field populations of Rhynchosporium secalis collected from the Wagga Wagga Agricultural Institute (WWAI), Methul, Rannock (Rann), Horsham (Horsh), and Quindanning (Quindan) during the 1996 barley-growing season

\begin{tabular}{|c|c|c|c|c|c|c|}
\hline Loci & Allele ${ }^{a}$ & WWAI & Methul & Rann & Horsh & Quindan \\
\hline \multirow[t]{3}{*}{ RS37 } & 1 & 0.68 & 0.75 & 0.82 & 0.56 & 0.68 \\
\hline & 3 & 0.32 & 0.25 & 0.18 & 0.44 & 0.05 \\
\hline & 4 & 0.00 & 0.00 & 0.00 & 0.00 & 0.28 \\
\hline \multirow[t]{4}{*}{ RS35 } & 1 & 0.42 & 0.45 & 0.57 & 0.65 & 0.26 \\
\hline & 2 & 0.42 & 0.46 & 0.33 & 0.12 & 0.26 \\
\hline & 3 & 0.00 & 0.05 & 0.05 & 0.00 & 0.44 \\
\hline & 10 & 0.10 & 0.00 & 0.02 & 0.18 & 0.00 \\
\hline \multirow[t]{4}{*}{ RS6 } & 3 & 0.00 & 0.09 & 0.00 & 0.00 & 0.29 \\
\hline & 4 & 0.61 & 0.38 & 0.51 & 0.15 & 0.31 \\
\hline & 6 & 0.16 & 0.33 & 0.16 & 0.21 & 0.02 \\
\hline & 8 & 0.23 & 0.16 & 0.33 & 0.62 & 0.38 \\
\hline \multirow[t]{3}{*}{ RS47 } & 1 & 0.47 & 0.56 & 0.49 & 0.54 & 0.33 \\
\hline & 2 & 0.21 & 0.07 & 0.11 & 0.00 & 0.14 \\
\hline & 3 & 0.32 & 0.37 & 0.40 & 0.46 & 0.52 \\
\hline \multirow[t]{3}{*}{ RS52 } & 1 & 0.07 & 0.11 & 0.07 & 0.05 & 0.26 \\
\hline & 2 & 0.62 & 0.65 & 0.62 & 0.62 & 0.74 \\
\hline & 3 & 0.31 & 0.24 & $0.32^{b}$ & 0.33 & 0.00 \\
\hline \multirow[t]{4}{*}{ RS36 } & 1 & 0.00 & 0.05 & 0.08 & 0.03 & 0.00 \\
\hline & 2 & 0.53 & 0.36 & 0.25 & 0.45 & 0.52 \\
\hline & 3 & 0.37 & 0.54 & 0.67 & $0.53^{b}$ & 0.48 \\
\hline & 5 & 0.08 & 0.05 & 0.00 & 0.00 & 0.00 \\
\hline \multirow[t]{2}{*}{$\mathrm{RS} 2$} & 1 & 0.47 & 0.21 & 0.59 & 0.68 & 0.37 \\
\hline & 2 & 0.53 & 0.79 & 0.41 & 0.32 & 0.63 \\
\hline
\end{tabular}

a Alleles present at frequencies lower than 0.05 across all five populations are not shown.

b Summed frequencies are greater than 1.0 due to rounding error. 
were found in the Australian populations (Table 2). Nei's (30) measure of gene diversity averaged across the seven loci ranged from 0.50 to 0.55 within populations. Stoddart and Taylor's (41) measure of genotype diversity ranged from 45 to $97 \%$ of its theoretical maximum (equal to sample size) across the five populations (Table 2). The collection from Rannock had the highest genotype diversity, with 60 genotypes identified among 61 isolates.

Distribution of genetic diversity within and among populations. The majority of gene and genotype diversity was distributed on a small spatial scale. Hierarchical gene diversity analysis indicated that $\approx 5 \%$ of total gene diversity was distributed among field populations, $18 \%$ among sampling sites within a field, and $76 \%$ within sites within a field. Genotype diversity also was distributed on a fine scale, except in the West Australia (Quindanning) field population. In Methul, Rannock, and Horsham, an average of 7.8 genotypes were found among 8.7 isolates sampled from each site within each field. Isolates with the same DNA fingerprints and multilocus haplotypes were found in the same field site, with only one case (in Horsham) in which the same clone was shared between different sites within a field. In contrast, the Quindanning population had an average of 4.1 genotypes among 7.0 isolates sampled from each field site, and 3 identical genotypes were found at two or three sites within this field. There were 13 cases in which the same multilocus haplotype was found in different field populations. DNA fingerprints showed that isolates having the same multilocus haplotype were genetically different in 10 of the cases. In the other three cases, the DNA fingerprints were similar, but could not be identified with certainty because the number of hybridizing fragments was small, with only three to four hybridizing fragments per case.

Genetic diversity was detected at the smallest spatial scale sampled. In five of eight cases, different genotypes were found among isolates drawn from different parts of the same lesions. For the 58 cases in which different lesions were sampled from the same leaf, different genotypes were found 45 times.

Population differentiation and isolation by distance. Significant differences in allele frequencies existed among populations

TABLE 2. Sample sizes, average gene diversities (Nei and Chesser [31]) and indicators of genotype diversity for five Australian Rhynchosporium secalis field populations sampled in 1996

\begin{tabular}{lcccc}
\hline Population & $\begin{array}{c}\text { Sample } \\
\text { size }\end{array}$ & $\begin{array}{c}\text { Gene } \\
\text { diversity }\end{array}$ & $\begin{array}{c}\text { No. of } \\
\text { genotypes }^{\mathrm{a}}\end{array}$ & $\begin{array}{c}\text { Percentage of } \\
\text { maximum }^{\mathrm{b}}\end{array}$ \\
\hline Wagga Wagga & 66 & 0.548 & 49 & 48 \\
Methul & 57 & 0.517 & 51 & 80 \\
Rannock & 61 & 0.505 & 60 & 97 \\
Horsham & 39 & 0.506 & 29 & 55 \\
Quindanning & 42 & 0.538 & 25 & 45 \\
\hline
\end{tabular}

${ }^{a}$ Based on combination of DNA fingerprints and multilocus haplotypes.

${ }^{b}$ Genotype diversity expressed as percentage of maximum possible value of Stoddart and Taylor (43). for all RFLP loci (Table 3). The level of population differentiation ranged from 0.03 to 0.11 across the seven RFLP loci, with an average of 0.07 . Pairwise comparisons of genotype diversity and genetic distance are shown in Table 4. Significant differences in genotype diversity were found in 6 of 10 comparisons. Further analysis by the Bonferroni procedure corroborated the significance of differences across all populations at $P<0.01$. The correlation coefficient between degree of gene flow and geographic distance was -0.79 (Fig. 3), which was significant at $P<0.05$, indicating a significant decrease in $\mathrm{Nm}$ as distance between populations increased.

\section{DISCUSSION}

The goal of our study was to use RFLP markers to characterize the genetic structure of $R$. secalis populations in Australia. Unlike plants and animals, fungi have few morphological characters that can be used to study their population biology. DNA markers, however, have provided a powerful tool for this type of study. Over the last decade, DNA markers have been used to quantify genetic variation $(4,38)$, decipher spatial distribution (27), and distinguish among forces that generate and maintain genetic variation $(47,48)$ for several agriculturally important fungi. Our study is the first to use anonymous RFLP markers to examine the genetic structure of $R$. secalis populations. Our results showed that Australian populations of $R$. secalis were highly variable and that the great majority of genetic variation was distributed within fields on a fine spatial scale. Collections made from different locations in southern Australia showed a moderate to high degree of genetic similarity. However, it appears that the Western Australia (Quindanning) population is genetically distinct from the other sampled populations.

Because $R$. secalis is thought to reproduce exclusively asexually, it was expected that populations of this fungus would display low genotype diversity among a limited number of clonal lineages. Our observations did not support this hypothesis, however. Many distinct genotypes were recovered from each field population over relatively small geographic areas. In the Methul field population, 60 genotypes could be differentiated among 61 isolates analyzed. High genetic diversity and relatively low levels of clonality (except for Quindanning) indicated that the field populations of $R$. secalis originated from genetically diverse source populations. The effective population size of $R$. secalis in Australian barley fields appears sufficiently large to limit the effects of genetic drift caused by seasonal epidemic cycles.

Hierarchical analysis $(5,30)$ enabled us to partition the total genetic variation among several spatial scales for the three populations from southern Australia (Horsham, Methul, and Rannock) included in this analysis. The geographic distances among these populations ranged from 15 to $500 \mathrm{~km}$. We partitioned total gene diversity into three components. The majority of gene diversity $(76 \%)$ was distributed within field sampling units covering an area of $\approx 1 \mathrm{~m}^{2}$. Only $5 \%$ of gene diversity was distributed among field populations in our survey; a finding that is consistent with a previous study showing

TABLE 3. Contingency $\chi^{2}$ test for differences in allele frequencies and $G_{\mathrm{ST}}$ (population differentiation) across five field populations of Rhynchosporium secalis from Australia

\begin{tabular}{|c|c|c|c|c|c|c|c|c|c|c|c|c|c|}
\hline \multirow{2}{*}{$\begin{array}{l}\text { RFLPa } \\
\text { loci }\end{array}$} & \multicolumn{2}{|c|}{$\chi^{2}$ Test } & \multicolumn{11}{|c|}{ Pairwise comparisons of population subdivision $\left(G_{\mathrm{ST}}\right)^{\mathrm{b}}$} \\
\hline & Value $^{\mathrm{c}}$ & df & $\mathrm{C} 1-\mathrm{C} 2$ & $\mathrm{C} 1-\mathrm{C} 3$ & $\mathrm{C} 1-\mathrm{C} 4$ & $\mathrm{C} 1-\mathrm{C} 5$ & $\mathrm{C} 2-\mathrm{C} 3$ & $\mathrm{C} 2-\mathrm{C} 4$ & $\mathrm{C} 2-\mathrm{C} 5$ & C3-C4 & C3-C5 & C4-C5 & Overall \\
\hline RS37 & $77.2 * * *$ & 8 & 0.006 & 0.024 & 0.013 & 0.068 & 0.006 & 0.040 & 0.066 & 0.077 & 0.070 & 0.110 & 0.071 \\
\hline RS35 & $93.3 * * *$ & 16 & 0.037 & 0.010 & 0.009 & 0.109 & 0.014 & 0.074 & 0.081 & 0.033 & 0.091 & 0.139 & 0.084 \\
\hline RS47 & $16.1^{*}$ & 8 & 0.014 & 0.010 & 0.028 & 0.028 & 0.003 & 0.006 & 0.034 & 0.007 & 0.017 & 0.030 & 0.025 \\
\hline RS52 & $26.9 * * *$ & 8 & 0.027 & 0.019 & 0.018 & 0.090 & 0.004 & 0.006 & 0.046 & 0.000 & 0.074 & 0.087 & 0.040 \\
\hline RS36 & $29.7 * *$ & 12 & 0.005 & 0.007 & 0.015 & 0.032 & 0.016 & 0.005 & 0.016 & 0.030 & 0.057 & 0.004 & 0.047 \\
\hline
\end{tabular}

${ }^{a}$ Restriction fragment length polymorphism.

b $\mathrm{C} 1, \mathrm{C} 2, \mathrm{C} 3, \mathrm{C} 4$, and C5 are population samples collected from Wagga Wagga, Methul, Rannock, Horsham, and Quindanning, respectively.

c *, **, and *** indicate significance at $P=0.05,0.01$, and 0.001 , respectively. 
that the majority of isozyme genetic variation was distributed within regions (13). Our results suggest that $R$. secalis propagules are effectively disseminated over spatial scales of at least hundreds of kilometers, leading to only minor differences in the distribution of genetic diversity among field populations on a regional scale. Conidia dispersed by rainsplash are not expected to travel long distances, so it is unlikely that these populations are linked by movement of conidia. It is more likely that gene flow among these populations occurs through infected seeds, fungal spores (possibly ascospores from the unknown teleomorph), or infected plant material in hay, which can be disseminated over longer distances.

The fact that $95 \%$ of the total RFLP variation was distributed within fields suggests that $R$. secalis populations have the potential to evolve relatively quickly. High diversity in neutral RFLP markers does not mean that diversity in phenotypic characters, such as virulence, also will be high. We did not test isolate virulence, however. It is possible that diversity for virulence is much lower than diversity for RFLPs, especially if there is strong selection due to scald-resistance genes present in a barley population. One advantage of neutral genetic markers is that they allow determination of pathogen genetic structure independent of selection. In this case, our data showed that Australian field populations of $R$. secalis are composed of many genotypes distributed on a small spatial scale. We believe that this genetic structure offers greater evolutionary potential than a clonal genetic structure (such as Puccinia graminis f. sp. tritici in Australia or the Great Plains of the United States), in which few genotypes are widely distributed. We hypothesize that the diverse $R$. secalis populations in Australia could adapt rapidly to newly introduced resistance genes, and therefore, the traditional method of introducing single major resistance genes into good agronomic cultivars may not provide long-term control of barley scald disease (13).

The larger pairwise genetic distances (Table 4) and lower genotype diversity found in the Quindanning population compared with other field populations suggest that the $R$. secalis population originating from Western Australia differed significantly from the other populations. We have considered four possible explanations for the genetic differentiation between the two regions. The first possibility is that adaptation to the local environment, including barley cultivars with different resistance genes, has led to genetic differentiation. Selection for virulence genes or linked genes (hitchhiking) that overcome resistance in local cultivars could lead to adaptation to local environments and promote genetic divergence of populations. In our case, selection would need to operate on anonymous RFLP markers or linked loci (28) to cause population differentiation. This possibility is considered unlikely because the probes used were selected from a random sample of fragments of total genomic DNA.

A second possibility is population subdivision due to limited gene flow between Western Australia and other populations. Restricted

TABLE 4. Pairwise comparisons of genotype diversity (Stoddart and Taylor [43], above diagonal) and genetic distances (Nei and Chesser [30], below diagonal) among populations collected from different geographic locations in Australia

\begin{tabular}{llllll}
\hline Population & $\begin{array}{l}\text { Wagga } \\
\text { Wagga }\end{array}$ & Methul & Rannock & Horsham & Quindanning \\
\hline Wagga Wagga & $\ldots$ & $\begin{array}{l}2.013^{* a} \\
(111)^{\mathrm{b}}\end{array}$ & $\begin{array}{l}3.513^{* * *} \\
(121)\end{array}$ & $\begin{array}{l}0.424 \\
(99)\end{array}$ & $\begin{array}{l}0.200 \\
(102)\end{array}$ \\
Methul & 0.067 & $\ldots$ & $\begin{array}{l}1.630 \\
(116)\end{array}$ & $\begin{array}{l}1.794 * \\
(94)\end{array}$ & $\begin{array}{l}3.085^{* *} \\
(97)\end{array}$ \\
Rannock & 0.059 & 0.069 & $\ldots$ & $\begin{array}{l}3.639 * * * \\
(98)\end{array}$ & $\begin{array}{l}6.383^{* * *} \\
(101)\end{array}$ \\
Horsham & 0.233 & 0.179 & 0.083 & $\ldots$ & $\begin{array}{l}0.803 \\
(79)\end{array}$ \\
Quindanning & 0.240 & 0.155 & 0.161 & 0.237 & $\ldots$ \\
\hline
\end{tabular}

a Student's $t$ test values. *, **, and $* * *$ indicate significance at $P=0.05,0.01$, and 0.001 , respectively.

b Degrees of freedom. gene flow among geographically isolated populations allows random fixation of different neutral alleles as a result of genetic drift. Under a model in which gene flow decreases with increasing distance, organisms exhibiting restricted dispersal are expected to show genetic isolation by distance $(28,39)$. The isolation by distance model is supported by our results. There was a significant negative correlation between the logarithm of $\mathrm{Nm}$ and the logarithm of distance between populations. In Australia, there can be significant movement of farm products (especially straw used for animal feed) between east and west as a result of regional droughts. This could offer a mechanism for periodic gene flow over long distances.

A third possibility is that the Western Australia population had a different origin or was introduced at a different time than the other populations. We do not know when $R$. secalis was introduced into Australia or whether there were several independent introductions. Comparisons with other populations around the world may permit testing of this hypothesis. A fourth possibility is that the Quindanning field population is not representative of Western Australia and that the apparent differences between regions are an artifact of limited sampling. This possibility can be tested with additional collections from Western Australia.

The amount of genetic variation measured in our study was higher than the variation found in previous studies based on isozymes. Goodwin et al. (14) found that the isozyme gene diversity in $R$. secalis populations collected from Australia ranged from 0.123 to 0.169. It is likely that RFLP markers are more sensitive and offer higher resolution than isozyme markers. During the development of RFLP markers, we used a California collection of $R$. secalis that had been characterized previously with isozymes (26). The most common isozyme multilocus haplotype (based on four isozyme loci) in the California field population was found 11 times in our reference sample of 52 isolates. The isozyme haplotype was resolved into three distinct RFLP haplotypes based on four RFLP loci. Seven DNA fingerprints were found among the eleven strains with the repetitive probe pRS26. The increased genetic diversity found also could be caused by the larger number of isolates evaluated in our sample. Our sample size was large enough to detect low-frequency alleles that have the potential to increase the overall measure of gene diversity. Although there was no evidence of significant population differentiation based on $G_{\mathrm{ST}}$, the collections from southern Australia had significant differences in allele frequency for several loci (results not shown), indicating the sample sizes in our study were large enough to detect minor differences among populations.

The amount and distribution of genetic diversity found in field populations of $R$. secalis were similar to those found in Mycosphaerella graminicola (11) and Phaeosphaeria nodorum (22). Field populations of $M$. graminicola and $P$. nodorum are characterized

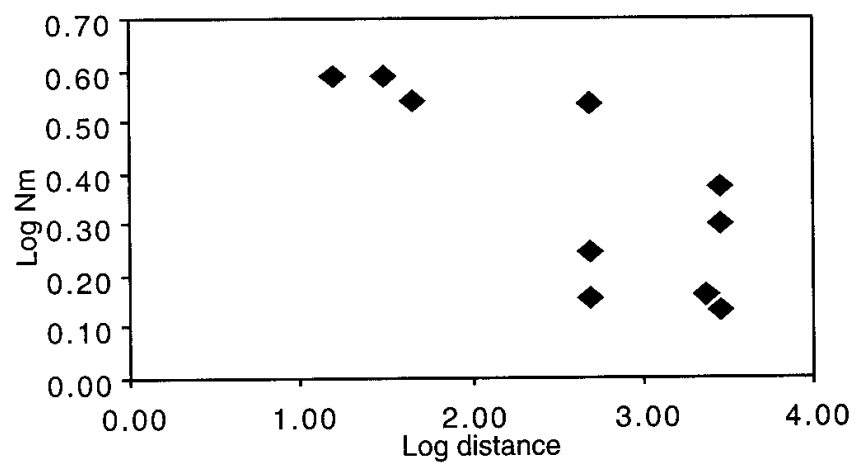

Fig. 3. Correlation between the logarithm of estimated number of migrants per generation $(\mathrm{Nm})$ between each pair of populations and the logarithm of geographic distance for Rhynchosporium secalis populations collected from different locations in Australia. $N m$ was estimated using average $G_{\mathrm{ST}}$ (population differentiation) across seven restriction fragment length polymorphism loci (30). 
by a high degree of sexual reproduction $(11,21,47,48)$. Airborne ascospores serve as the primary inoculum to establish field populations of $M$. graminicola (33-36), and we have proposed that ascospores also are the primary inoculum for $P$. nodorum (21, 22). After establishment, populations of these fungi expand through a mixture of sexual and asexual reproduction $(17,21,22$, $36,47,48)$. The sexual stage has not been reported for $R$. secalis, but a recent study with isozyme markers (8) showed that most of the alleles at isozyme loci were in gametic equilibrium. We have obtained similar results with larger sample sizes based on RFLP data (B. A. McDonald, J. Zhan, and J. J. Burdon, unpublished data). It is possible that the sexual stage of $R$. secalis occurs on stubble between growing seasons and plays some role in the establishment of a founder population, followed by exclusively asexual propagation. We plan to test this hypothesis by monitoring changes in the genetic structure of field populations over the growing season.

\section{ACKNOWLEDGMENTS}

Undergraduate students L. Setchfield, P. Bushong, and F. Garcia made the $R$. secalis DNA library, screened the library to find polymorphic probes, and collected the first California data set. The students were supported by National Science Foundation Grant DEB-9306377. R. Pettway supervised the students with support from the Texas Agricultural Experiment Station. B. Read assisted with all collections made near the Wagga Wagga Agricultural Institute. D. Moody and R. Loughman made field collections near Horsham and Perth, respectively. R. Heywood provided technical assistance. B. A. McDonald thanks the Australian Grains Research and Development Council for the support provided by a Visiting Fellowship (VF22).

\section{LITERATURE CITED}

1. Abbott, D. C., Burdon, J. J., Jarosz, A. M., Brown, A. H. D., Muller, W. J., and Read, B. J. 1991. The relationship between seedling infection types and field reactions to leaf scald in Clipper barley backcross lines. Aust. J. Agric. Res. 42:801-809.

2. Ali, S. M., Mayfield, A. H., and Clare, B. G. 1976. Pathogenicity of 203 isolates of Rhynchosporium secalis on 21 barley cultivars. Plant Pathol. 9:135-143.

3. Ayesu-Offei, E. N., and Carter, M. V. 1971. Epidemiology of leaf scald of barley. Aust. J. Agric. Res. 22:383-390.

4. Balardin, R. S., Jarosz, A. M., and Kelly, J. D. 1997. Virulence and molecular diversity in Colletotrichum lindemuthianum from South, Central, and North America. Phytopathology 87:1184-1191.

5. Beckwitt, R., and Chakraborty, R. 1980. Genetic structure of Pileolaria pseudomilitaris (Polychaeta: Spirorbidae) Genetics 96:711-726.

6. Braiser, C. M. 1988. Rapid changes in genetic structure of epidemic populations of Ophiostoma ulmi. Nature 332:538-541.

7. Brown, J. S. 1985. Pathogenic variation among isolates of Rhynchosporium secalis from cultivated barley growing in Victoria, Australia. Euphytica 34:129-133.

8. Burdon, J. J., Abbott, D. C., Brown, A. H. D., and Brown, J. S. 1994. Genetic structure of the scald pathogen (Rhynchosporium secalis) in south east Australia: Implications for control strategies. Aust. J. Agric. Res. 45: 1445-1454.

9. Ceoloni, C. 1980. Race differentiation and search for sources of resistance to Rhynchosporium secalis in barley in Italy. Euphytica 29:547-553.

10. Chen, R. S., Boeger, J. M., and McDonald, B. A. 1994. Genetic stability in a population of a plant pathogenic fungus over time. Mol. Ecol. 3: 209-218.

11. Chen, R. S., and McDonald, B. A. 1996. Sexual reproduction plays a major role in the genetic structure of populations of the fungus Mycosphaerella graminicola. Genetics 142:1119-1127.

12. Fowler, A. M., and Owen, H. 1971. Studies of leaf blotch of barley (Rhynchosporium secalis). Trans. Br. Mycol. Soc. 56:137-152.

13. Goodwin, S. B., Allard, R. W., Hardy, S. A., and Webster, R. K. 1992. Hierarchical structure of pathogenic variation among Rhynchosporium secalis populations in Idaho and Oregon. Can. J. Bot. 70:811-817.

14. Goodwin, S. B., Saghai Maroof, M. A., Allard, R. W., and Webster, R. K. 1993. Isozyme variation within and among populations of Rhynchosporium secalis in Europe, Australia and the United States. Mycol. Res. 97: 49-58.

15. Habgood, R. M. 1973. Variation in Rhynchosporium secalis. Trans. Br. Mycol. Soc. 61:41-47.
16. Houston, B. R., and Ashworth, L. J. 1957. Newly determined races of the barley scald fungus in California. (Abstr.) Phytopathology 47:525.

17. Hunter, T., Coker, R. R., and Royle, D. J. 1999. The teleomorph stage, Mycosphaerella graminicola, in epidemics of Septoria tritici blotch on winter wheat in the UK. Plant Pathol. 48:51-57.

18. Jackson, L. F., and Webster, R. K. 1976. Race differentiation, distribution, and frequency of Rhynchosporium secalis in California. Phytopathology 66:719-725.

19. Jeffreys, A. J., Wilson, V., and Thein, S. L. 1985. Individual-specific 'fingerprints' of human DNA. Nature 316:76-79.

20. Jørgensen, H. J. L., and Smedegaard-Peterson, V. 1995. Pathogenic variation of Rhynchosporium secalis in Denmark and sources of resistance in barley. Plant Dis. 79:297-301.

21. Keller, S. M., McDermott, J. M., Pettway, R. E., Wolfe, M. S., and McDonald, B. A. 1997. Gene flow and sexual reproduction in the wheat glume blotch pathogen Phaeosphaeria nodorum (anamorph Stagonospora nodorum). Phytopathology 87:353-358.

22. Keller, S. M., Wolfe, M. S. McDermott, J. M., and McDonald, B. A. 1997. High genetic similarity among populations of Phaeosphaeria nodorum across wheat cultivars and regions in Switzerland. Phytopathology 87:1134-1139.

23. Khan, T. N. 1986. Effect of fungicide treatment on scald (Rhynchosporium secalis (Oud.) J. Davis) infection on some quality characteristics of barley. Aust. J. Exp. Agric. 28:783-785.

24. Maniatis, T., Fritsch, E. F., and Sambrook, J. 1982. Molecular Cloning: A Laboratory Manual. Cold Spring Harbor Laboratory, Cold Spring Harbor, NY.

25. McDermott, J. M., McDonald, B. A., Allard, R. W., and Webster, R. K. 1989. Genetic variability for pathogenicity, isozyme, ribosomal DNA and colony color variants in populations of Rhynchosporium secalis. Genetics 122:561-565.

26. McDonald, B. A., McDermott, J. M., Allard, R. W., and Webster, R. K. 1989. Coevolution of host and pathogen populations in the Hordeum vulgareRhynchosporium secalis pathosystem. Proc. Natl. Acad. Sci. USA 86:39243927.

27. Milgroom, M. G., and Lipari, S. E. 1995. Spatial analysis of nuclear and mitochondrial RFLP genotypes in populations of the chestnut blight fungus, Cryphonectria parasitica. Mol. Ecol. 4:633-642.

28. Milgroom, M. G., Wang, K., Zhou, Y., and Kaneko, S. 1996. International population structure of chestnut blight fungus, Cryphonectria parasitica. Mycologia 88:179-190.

29. Nei, M. 1972. Genetic distance between populations. Am. Nat. 106:283-292.

30. Nei, M. 1973. Analysis of gene diversity in subdivided populations. Proc. Natl. Acad. Sci. USA 70:3321-3323.

31. Nei, M., and Chesser, R. K. 1983. Estimation of fixation indices and gene diversities. Ann. Hum. Genet. 47:253-259.

32. Newman, P. L., and Owen, H. 1985. Evidence of asexual recombination in Rhynchosporium secalis. Plant Pathol. 34:338-340.

33. Sanderson, F. R. 1972. Mycosphaerella graminicola (Fuckel) Sanderson comb. nov., the ascogenous state of Septoria tritici Rob. and Desm. N.Z. J. Bot. 14:359-360.

34. Sanderson, F. R., and Hampton, J. G. 1978. Role of the perfect states in the epidemiology of the common Septoria diseases of wheat. N.Z. J. Agric. Res. 21:277-281.

35. Shaw, M. W., and Royle, D. J. 1987. Spatial distributions of Septoria nodorum and Septoria tritici within crops of winter wheat. Plant Pathol. 36:84-94.

36. Shaw, M. W., and Royle, D. J. 1989. Airborne inoculum as a major source of Septoria tritici (Mycosphaerella graminicola) infections in winter wheat crops in the UK. Plant Pathol. 38:35-43.

37. Shipton, W. A., Boyd, W. J. R., and Ali, S. M. 1974. Scald of barley. Rev. Plant Pathol. 53:840-861.

38. Sicard, D., Michalakis, Y., Dron, M., and Neemu, C. 1997. Genetic diversity and pathogenic variation of Colletotrichum lindemuthianum in the three centers of diversity of its host, Phaseolus vulgaris. Phytopathology 87:807-813.

39. Slatkin, M. 1993. Isolation by distance in equilibrium and non-equilibrium populations. Evolution 47:264-279.

40. Stedman, O. J. 1980. Observation on the production and dispersal of spores, and infection by Rhynchosporium secalis. Ann. Appl. Biol. 95:163-175.

41. Stoddart, J. A., and Taylor, J. F. 1988. Genotypic diversity: Estimation and prediction in samples. Genetics 118:705-711.

42. Tekauz, A. 1991. Pathogenic variation in Rhynchosporium secalis on barley in Canada. Can. J. Plant Pathol. 13:298-304.

43. Watson, I. A. 1981. Wheat and its rust parasites in Australia. Pages 129147 in: Wheat Science-Today and Tomorrow. L. T. Evans and W. J. Peacock, eds. Cambridge University Press: Cambridge.

44. Weir, B. S. 1997. Genetic Data Analysis II. Sinauer Associates Inc., Sunderland, MA. 
45. Workman, P. L., and Niswander, J. D. 1970. Population studies on Southwestern Indian tribes. II. Local genetic differentiation in the Papago. Am. J. Hum. Genet. 22:24-49.

46. Xue, G., and Hall, R. 1991. Components of parasitic fitness in Rhynchosporium secalis and quantitative resistance to scald in barley as determined with a dome inoculation chamber. Can. J. Plant Pathol. 13:19-25.

47. Zhan, J. 1998. The role of immigration, mating system and selection on the genetic structure of populations of the wheat pathogen Mycosphaerella graminicola. Ph.D. dissertation. Texas A\&M University, College Station.
48. Zhan, J., Mundt, C. C., and McDonald, B. A. 1998. Measuring immigration and sexual reproduction in field populations of Mycosphaerella graminicola. Phytopathology 88:1330-1337.

49. Zhang, Q., Webster, R. K., and Allard, R. W. 1987. Geographical distribution and associations between resistance to four races of Rhynchosporium secalis. Phytopathology 77:352-357.

50. Zhang, Q., Webster, R. K., Crandall, B. A., Jackson, L. F., and Sagahi Maroof, M. A. 1992. Race composition and pathogenicity associations of Rhynchosporium secalis in California. Phytopathology 82:798-803. 